\title{
Instant Hijab Designs for Urban Muslim Women
}

\author{
Indarti \\ Department of Home Economics \\ Universitas Negeri Surabaya \\ Surabaya, Indonesia \\ indarti@unesa.ac.id
}

\author{
Li-Hsun PENG \\ Department of Creative Design \\ National Yunlin University of Science \& Technology \\ Douliou City, Taiwan \\ penglh@gemail.yuntech.edu.tw
}

\begin{abstract}
This research examines the adoption of an innovative hijab design for urban Muslim women that is both fashionable and is easy to wear. Participants were 20 young urban hijabistas $(\mathrm{M}=27)$ with expertise in fashion design. The data were collected in May 2017, via social media (Facebook). This study used descriptive statistics to analyze six aspects of five hijab designs: style, structures, details, materials, fashionable, and wearables. The result shows that wearable or easy to wear is the best variables in this study. This concept of instant hijab is uniting the bonnet and scarf together, so simpler to wear it. The best design among five hijab that have been examined is design 3 and 4. This instant hijab is easy to wear because we have been patterning and sewing in some parts making it easier to wear. The concept of this instant hijab is uniting the bonnet and scarf together, so simpler to wear it. The bonnet is made from spandex because it has elasticity to follow the shape of the head. Instant hijab designs in this research is as enrichment in the selection of hijab for urban Muslim women.
\end{abstract}

Keywords-Muslim fashion; hijab; fashionista; fashionable; wearable

\section{INTRODUCTION}

Islamic clothing has recently become a trend in the world such as Indonesia, Turkey and Malaysia. The growing popularity of Islamic clothing in Indonesia, Muslim fashion has become an increasingly hot topic among wearers of Islamic clothing [1]. Urban Indonesian women increasingly adopt a form of Islamic dress called busana muslim because of a rise in Islamic piety and a rise in consumerism [2]. Since the 1980s, fashionable Islamic dress for women, has become a growing segment of the textile industry in Turkey [4].The veilingfashion industry in Turkey has emerged over the past three decades from a particular constellation of political, economic, and cultural shifts [4]. The current representations of the hijab offer a favorable status quo for Malay-Muslim women through marketing strategies that emphasize fashion trends and class mobility [5].

The term Muslim dress denotes any outfit including a head cover. The head cover is called veil [6], khimar [7], jilbab [8] (Tarlo, 2005) and hijab. Hijab is the veiling of women in Islamic society, customarily practiced in order to maintain standards of modesty [9]. The term of hijab is a commonly used representation of the veil in Muslim culture [10]. Hijab is usually a square of cloth folded into a triangle that is draped over the head and squared around the neck by tying pinning it in place [11].
Urban Muslim women are easier to access information via internet. Like other women, they follow new life style including the fashion from internet. Urban Muslim women have good education or job and they wear fashionable hijab. Urban Muslim women is related with hijabista. Hijabista is young, fashion conscious Muslim women who wear the hijab in new and creative ways that showcase their performance of agency, beauty and piety [12]. They wear the current fashionable hijab which spread on the internet, social media, magazine and television. Urban Muslim women usually have a busy life, they go to work or school in a busy city atmosphere. The instant hijab is offered to fill the needs of urban Muslim women wore the easy hijab.

A fashionable hijab is usually a rectangular scarf that is wrapped around the head multiple times and pinned to an underscraft. The pinning and wrapping makes it more complicated to wear. Urban Muslim women have busy life atmosphere. Everything for quickly is needed in the life. This research examines the adoption of an innovative hijab design for urban Muslim women that is both fashionable and is easy to wear. We offer five instant hijab designs which is observed by hijabistas on several aspects.

\section{METHODS}

\section{A. Participants}

Participants were 20 young urban hijabistas with expertise in fashion design. They are alumni of fashion design major of Universitas Negeri Surabaya. The participants were between age 22 and $31(M=27)$. Participants live in around Surabaya. Almost of them are entrepreneur $(65 \%)$ in fashion design fields, fashion educators (20\%) and others (15\%).

\section{B. Procedure}

We design 5 instant hijab for urban Muslim women that have characteristic fashionable and easy to wear (see appendix). The hijabistas examined this 5 designs. The hijab wore by model that showed the steps of how to wear. The steps indicate that the hijab is easy to wear and shows the details of hijab. Every design has four steps and taken pictures every step. The pictures organized as media to take data. The participants given opinion of every design.

The data were collected in May 2017, via social media (Facebook). The emergence of Internet-based social media has made it possible for one person to communicate with hundreds or even thousands of other people [13]. Created in February 
2004 by Mark Zuckerberg, a Harvard undergraduate student, Facebook, with its 21 million registered users and 1.6 billion page views each day, is one of the fastest growing social network sites [14].

\section{Measurements and Analysis}

Respondent were asked to give their opinion on five hijab designs. The aspects of measurements of hijab designs are style, structure, details, materials, fashionable, and wearable. Style is a particular kind or type or characteristic mode. Style of garment is usually affected by physical attribute and the context [15]. Structure (shape, form) is defined as a two or more dimensional area that stands out from the space next to or around it due to a defined or implied boundary. It is one of elements of design. Details can be used to give a collection of clothes a unique identity or signature [16]. Materials or medium is meant fabrics. Combination of materials properties which establish performance [17]. The innovative hijab designs for urban Muslim women is fashionable and easy to wear (wearable). Fashionable is conforming to the current styles or trends.

The opinion of hijabistas as participants was measured on a five-point Likert-format scale, ranging from very poor to very good for style, structure, details and materials. A five point scale from disagree to strongly disagree for opinion about fashionable and wearable variables. Data were analyzed using descriptive statistic.

\section{RESULTS AND DISCUSSION}

\section{A. Style}

Mean and Standard deviations of Style are detailed in table 1. There is two opinion of hijabistas about style of five designs. First the mean is less than 4 and more than 4 . The mean less than 4 is only in design 1 , other designs are more than 4 , it means design 2, 3, 4, and 5 are good.

\section{TABLE 1. MEAN AND STANDARD DEVIATIONS OF STYLE}

\begin{tabular}{|c|c|c|c|c|c|}
\hline Variable & Mean & Std. Dev. & $\begin{array}{c}\text { Mini- } \\
\text { mum }\end{array}$ & $\begin{array}{c}\text { Maxi- } \\
\text { mum }\end{array}$ & $\mathbf{N}$ \\
\hline $\operatorname{des} 1$ & 3.75 & 0.887412 & 2 & 5 & 20 \\
\hline $\operatorname{des} 2$ & 4.1 & 0.8306624 & 2 & 5 & 20 \\
\hline $\operatorname{des} 3$ & 4.15 & 0.6538348 & 3 & 5 & 20 \\
\hline $\operatorname{des} 4$ & 4.25 & 0.7664855 & 2 & 5 & 20 \\
\hline $\operatorname{des} 5$ & 4.1 & 0.8888194 & 2 & 5 & 20 \\
\hline
\end{tabular}

The opinion of hijabistas about style is good $(80 \%$ of designs). Style is a particular kind or type or characteristic mode. The characteristic of this designs are feminine, they have volume and drapery around head and neck. In dictionary drapery means coverings, hangings, and clothing of fabric especially as arranged in loose.

\section{B. Structure}

Mean and Standard deviations of Structure are detailed in table 2. There is two opinion of hijabistas about Structure of five designs. First the mean is less than 4 and more than 4 . The mean less than 4 is only in design 1 , other designs are more than 4 , it means design $2,3,4$, and 5 are good.

TABLE II.

\begin{tabular}{|l|l|l|l|l|l|}
\hline Variable & Mean & Std. Dev. & $\begin{array}{l}\text { Mini- } \\
\text { mum }\end{array}$ & $\begin{array}{l}\text { Maxi- } \\
\text { mum }\end{array}$ & N \\
\hline des 1 & 3.65 & 0.6538348 & 3 & 5 & 20 \\
\hline des 2 & 4.15 & 0.726292 & 3 & 5 & 20 \\
\hline des 3 & 4.1 & 0.5385165 & 3 & 5 & 20 \\
\hline des 4 & 4.1 & 0.8306624 & 2 & 5 & 20 \\
\hline des 5 & 4.05 & 0.8645808 & 2 & 5 & 20 \\
\hline
\end{tabular}

The opinion of hijabistas about structure of five designs are good on design 2, 3, 4, 5 and average on design $1.80 \%$ of hijab designs be liked by hiabistas. Structure is synonym with construction, form and shape. This variable is one of design elements. Structure or shape of this hijab is depend on the pattern construction. Shape-changing garments have used many forms of actuation technology to transform [18]. Designers reinterpreted the structure of garments on the body [19]. So the interpretation of the structure of hijab is accepted by young hijabistas in Indonesia.

\section{Details}

Mean and Standard deviations of Details are detailed in table 3. There is two opinion of hijabistas about Details of five designs. First the mean is less than 4 and more than 4 . The mean less than 4 is only in design 1 and 2, other designs are more than 4 , it means design 3,4 , and 5 are good.

TABLE III. MEAN AND STANDARD DEVIATIONS OF DETAILS

\begin{tabular}{|c|c|c|c|c|c|}
\hline Variable & Mean & Std. Dev. & $\begin{array}{c}\text { Mini- } \\
\text { mum }\end{array}$ & $\begin{array}{c}\text { Maxi- } \\
\text { mum }\end{array}$ & N \\
\hline des 1 & 3.55 & 0.7399324 & 2 & 5 & 20 \\
\hline des 2 & 3.9 & 0.9433981 & 1 & 5 & 20 \\
\hline des 3 & 4 & 0.8944272 & 1 & 5 & 20 \\
\hline $\operatorname{des} 4$ & 4.2 & 0.678233 & 3 & 5 & 20 \\
\hline des 5 & 4.1 & 0.8306624 & 2 & 5 & 20 \\
\hline
\end{tabular}

The opinion of hijabistas about structure of five designs are good on design 3, 4, 5 and average on design 1 and 2 . Details can be used to give a collection of clothes a unique identity or signature [16]. All of the hijab designs apply the details. The most hijabistas love design 3, 4 and 5. Design 3 applies pleats, design 4 applies pattern tucking, and design 5 uses batik for applique.

\section{Materials}

Mean and Standard deviations of Materials are detailed in table 4. There is two opinion of hijabistas about Materials of five designs. First the mean is less than 4 and more than 4 . The mean less than 4 is only in design 1 , other designs are more than 4 , it means design $2,3,4$, and 5 are good. 
TABLE IV. MEAN AND STANDARD DEVIATIONS OF MATERIALS

\begin{tabular}{|c|c|c|c|c|c|}
\hline Variable & Mean & Std. Dev. & $\begin{array}{c}\text { Mini- } \\
\text { mum }\end{array}$ & $\begin{array}{c}\text { Maxi- } \\
\text { mum }\end{array}$ & N \\
\hline des 1 & 3.95 & 0.4974937 & 3 & 5 & 20 \\
\hline des 2 & 4.05 & 0.5894913 & 3 & 5 & 20 \\
\hline $\operatorname{des} 3$ & 4.25 & 0.622495 & 3 & 5 & 20 \\
\hline $\operatorname{des} 4$ & 4.2 & 0.678233 & 3 & 5 & 20 \\
\hline $\operatorname{des} 5$ & 4.15 & 0.5722762 & 3 & 5 & 20 \\
\hline
\end{tabular}

The opinion of hijabistas about materials is good (80\% of designs). Materials or medium is meant fabrics. This designs use fabric from chiffon and spandex. Chiffon is a very lightweight, sheer, plain, weave fabric of fine, tightly twisted yarns [20]. Chiffon is a popular fabric used in blouses, ribbons, scarves and lingerie [21].Spandex is a highly elastic fiber with a light weight, and it is soft and smooth, spandex has been commonly used in clothes in order to provide them with high deformation and good elasticity [22].

\section{E. Fashionable}

Mean and Standard deviations of Fashionable measures are detailed in table 5. There is two opinion of hijabistas about style of five designs. First the mean is less than 4 and more than 4 . The mean less than 4 is only in design 1 and 5 , other designs are more than 4 , it means design 2,3 , and 4 are faashionable.

TABLE V. MEAN AND STANDARD DEVIATIONS OF FASHIONABLE

\begin{tabular}{|c|c|c|c|c|c|}
\hline Variable & Mean & Std. Dev. & $\begin{array}{c}\text { Mini- } \\
\text { mum }\end{array}$ & $\begin{array}{c}\text { Maxi- } \\
\text { mum }\end{array}$ & N \\
\hline des 1 & 3.9 & 0.7681146 & 2 & 5 & 20 \\
\hline des 2 & 4.05 & 0.6689544 & 3 & 5 & 20 \\
\hline des 3 & 4.05 & 0.6689544 & 3 & 5 & 20 \\
\hline des 4 & 4.3 & 0.5567764 & 3 & 5 & 20 \\
\hline des 5 & 3.9 & 0.9433981 & 2 & 5 & 20 \\
\hline
\end{tabular}

The opinion of hijabistas about this hijab designs are fashionable on design 2, 3, 4 and average on design 1 and 5 . The innovative hijab designs for urban Muslim women is fashionable and easy to wear (wearable). Fashionable is representing a current popular trend or style. The majority of Muslim countries now embrace Islamic cosmopolitanism which allows Muslim women to express their individually through the latest fashion trend with a variety of styles, accessories, and bold colors [23].

\section{F. Wearable}

Mean and Standard deviations of wearable measures are detailed in Table VI. The data statistic shows the mean of all of hijab designs are more than 4. It means all of the hijab designs are easy to wear or wearable.
TABLE VI. MEAN AND STANDARD DEVIATIONS OF WEARABLE

\begin{tabular}{|l|c|c|c|c|c|}
\hline Variable & Mean & Std. Dev. & $\begin{array}{c}\text { Mini- } \\
\text { mum }\end{array}$ & $\begin{array}{c}\text { Maxi- } \\
\text { mum }\end{array}$ & N \\
\hline des 1 & 4.3 & 0.9539392 & 1 & 5 & 20 \\
\hline des 2 & 4.3 & 0.4582576 & 4 & 5 & 20 \\
\hline des 3 & 4.4 & 0.4898979 & 4 & 5 & 20 \\
\hline des 4 & 4.45 & 0.5894913 & 3 & 5 & 20 \\
\hline des 5 & 4.25 & 0.698212 & 2 & 5 & 20 \\
\hline
\end{tabular}

The concept of instant hijab is easy to wear because we have been patterning and sewing in some parts making it easier to use. All of this hijab designs are easy to wear. Wearable or easy to wear is the best variables in this study. All hijabs are designed to be easy to use even though they look complicated. The modern hijab is related with bonnet or inner. The bonnet not only fits securely over the hair (ensuring that it stays hidden), but when wearer pins the two layers together it keeps the hijab from slipping off [11]. This concept of instant hijab is uniting the bonnet and scarf together, so simpler to wear it. The bonnet is made from spandex because it has elasticity to follow the shape of the head. The scarf can use chiffon or the same fabric of bonnet, spandex.

\section{CONCLUSION}

The result shows that wearable or easy to wear is the best variables in this study. This concept of instant hijab is uniting the bonnet and scarf together, so simpler to wear it. The best design among five hijab that have been examined is design 3 and 4 . This instant hijab is easy to wear because we have been patterning and sewing in some parts making it easier to wear. The concept of this instant hijab is uniting the bonnet and scarf together, so simpler to wear it. The bonnet is made from spandex because it has elasticity to follow the shape of the head. Instant hijab designs in this research is as enrichment in the selection of hijab for urban Muslim women.

\section{REFERENCES}

[1] Amrullah, E. F. Indonesian Muslim fashion Styles \& Designs. ISIM Review, 22, 2. 2008.

[2] Jones, C. Fashion and faith in urban Indonesia. Fashion Theory, 11(2-3), 2007, pp 211-231.

[3] Gökarıksel, B., \& Secor, A. Between Fashion and Tesettür Marketing and Consuming Women's Islamic Dress. Journal of Middle East Women's Studies, 6(3), 2010, pp 118-148.

[4] Jafari, A., \& Sandikci, Ö. (Eds.). (2016). Islam, Marketing and Consumption: Critical Perspectives on the Intersections. Routledge.

[5] Hassim, N., Nayan, S. M., \& Ishak, M. S. A. Hijabistas: An Analysis of the Mediation of Malay-Muslims and Modesty. Jurnal Pengajian Media Malaysia, 2016, 17(2).

[6] Bullock, K. Challenging Media representations of the veil: contemporary Muslim women's re-veiling movement. American Journal of Islamic Social Sciences, 17(3), 2000, 22.

[7] Shadid, W., \& Van Koningsveld, P. S. Muslim dress in Europe: debates on the headscarf. Journal of Islamic Studies, 16(1), 2005, pp 35-61.

[8] Jones, C. Materializing piety: Gendered anxieties about faithful consumption in contemporary urban Indonesia. American Ethnologist, 37(4), 2010, pp 617-637.

[9] Rehmani, M., The Hijab and Its Purpose: Understanding the Veil, Clearing Misconception. Kindle, 2016.

[10] Hamzeh, M. Z., \& Oliver, K. Gaining research access into the lives of Muslim girls: Researchers negotiating muslimness, modesty, inshallah, 
and haram. International Journal of Qualitative Studies in Education, 23(2), 2010, pp 165-180.

[11] Akou, H. M. Building a new "world fashion": Islamic dress in the twenty-first century. Fashion Theory, 11(4), 2007, pp 403-421.

[12] Shriver, C. M. What is Unveiled through Veiling: Understanding the Complex Narratives of the Modern Hijabista Movement. 2017.

[13] Mangold, W. G., \& Faulds, D. J. Social media: The new hybrid element of the promotion mix. Business horizons, 52(4), 2009, pp 357-365.

[14] Needham \& Company (2007). Needham Capital Partners. http://www.needhamcapital.com.

[15] Li, J., \& Li, Y. Cognitive model based fashion style decision making. Expert Systems with Applications, 39(5), 2012, pp 4972-4977.

[16] Seivewright, S. Basic Fashion Design: Research and Design. Switzerland: AVA Publishing. 2007.

[17] Ashby, M. F., \& Cebon, D. Materials selection in mechanical design. Le Journal de Physique IV, 1993, 3(C7), C7-1.
[18] Perovich, L., Mothersill, P., \& Farah, J. B. apparel: embedded soft actuators for expressive fashion and functional garments. In Proceedings of the 8th International Conference on Tangible, Embedded and Embodied Interaction (pp. 77-80). ACM. 2014, February). Awakened

[19] VURUSKAN, A., \& BURNS, A. (2017). AN APPROACH TO DEVELOP CREATIVITY BY UNDERSTANDING STRUCTURE IN FASHION DESIGN EDUCATION. Journal of Textile \& Apparel/Tekstil ve Konfeksiyon, 27(1).

[20] Koester, A. W. Fashion terms: apparel fabric glossary. 1992.

[21] Shehata, Z. The Study of the effect of the juxtaposition of specific materials on some seam properties. Life Science Journal, 12(3). 2015.

[22] Hu, J. J., Lu, P. C., Lou, C. W., Lee, M. C., \& Lin, J. H. Small-diameter vascular grafts composed of polyester/spandex fibers: Manufacturing techniques and property evaluations. Materials Letters, 171, 2016, pp 42-45.

[23] Hassan, S. H., \& Harun, H. Factors influencing fashion consciousness in hijab fashion consumption among hijabistas. Journal of Islamic Marketing, 7(4), 2016, pp 476-494. 